\title{
INFLUENCE OF LIPID EXTRACTION FROM DIFFERENT PROTEIN SOURCES ON in vitro DIGESTIBILITY
}

\author{
Influência da extração de lipídio de diferentes fontes protéicas na digestibilidade in vitro
}

\author{
Rita de Cássia Oliveira Sant'Ana', Fabrícia Queiroz Mendes², \\ Christiano Vieira Pires ${ }^{3}$, Maria Goreti de Almeida Oliveira ${ }^{1}$
}

\begin{abstract}
Proteins are the most abundant macromolecules in living cells and their primary role in the diet is to supply the body with essential amino acids in adequate quantities for the synthesis and maintenance of body tissues. The determination of protein digestibility of foods is an important factor to estimate their quality and the in vitro methodology is a fast and easy way to perform it. This study aimed to determine the influence of lipids on the in vitro digestibility of animal and vegetable proteins. The following protein sources: oat, beef, chicken, fish and pork meats, red beans, milk powder, textured soy protein (TSP), quinoa and five soybean varieties were evaluated. Animal proteins presented higher in vitro values than vegetable proteins, except for the textured soy protein, which presented higher digestibility based on the thermal treatment. In this study, there was no statistic difference between lipid content and protein digestibility. Therefore, there is no need that samples be defatted prior the analysis of the in vitro digestibility, using an enzymatic system containing the enzymes trypsin and pancreatin, which facilitates even more the use of these methods for foods with high lipid levels in food industries.
\end{abstract}

Index terms: Protein, quality, hydrolysis.

\section{RESUMO}

As proteínas são as macromoléculas mais abundantes nas células vivas, tendo como principal função na dieta suprir o organismo de aminoácidos indispensáveis em quantidades adequadas para síntese e manutenção dos tecidos corporais. Desse modo, a determinação da digestibilidade proteica de um alimento é um fator importante para estimar a sua qualidade, sendo o método in vitro uma alternativa rápida e fácil. Neste trabalho, objetivou-se determinar a influência dos lipídios na digestibilidade in vitro de proteínas de origem animal e vegetal. Foram utilizadas as seguintes fontes de proteína: aveia, carnes: bovina, de frango, de peixe e suína, feijão vermelho, leite em pó, proteína texturizada de soja (PTS), quinoa e cinco variedades de soja. As proteínas de origem animal apresentaram maiores valores de digestibilidade in vitro que as de origem vegetal, exceto a proteína texturizada de soja que apresentou maior digestibilidade, em razão do processamento a que foi submetido. No presente trabalho, não houve diferença estatística entre diferentes conteúdos de lipídios sobre a digestibilidade proteica. Desse modo, sugere-se não ser preciso desengordurar as amostras antes de analisar a digestibilidade in vitro, usando o sistema enzimático contendo as enzimas trispisna e pacreatina, tornando-se ainda mais fácil a utilização desses métodos para alimentos com alto teor de lipídio em indústrias de alimentos.

Termos para indexação: Proteína, qualidade, hidrólise.

\section{(Received in august 11, 2010 and approved in january 17, 2011)}

\section{INTRODUCTION}

Proteins play several roles in the organism, such as metabolism regulation, nutrient transport, natural catalysis activity, immune defense, membrane reception, among many others (WORLD HEALTH ORGANIZATION WHO, 2003). The protein quality describes the characteristics of a protein related to its capacity to carry out specific metabolic activities. Traditionally, this subject used to be discussed only focusing a protein food and its capacity to provide specific aminoacids to satisfy the demands for the protein synthesis and other specific metabolites. It is currently known that protein activities surpass the maintenance in the body and the metabolic demands of the biosynthetic pathways (MILLWARD et al., 2008).

Vegetable proteins are the main protein source for humans, mainly in developing countries, since animal proteins are generally more expensive (WONG; CHEUNG, 2001; CRUZ et al., 2004). Among vegetables, legumes are a good alternative of proteins and carbohydrates. They are among the main protein providers in areas where the sources of animal protein are scarce or expensive (ESTEVES et al., 2002).

\footnotetext{
1 Universidade Federal de Viçosa/UFV - Instituto de Biotecnologia Aplicada à Agropecuária/BIOAGRO - Viçosa, MG

${ }^{2}$ Universidade Federal de Viçosa/UFV - Viçosa, MG

3Universidade Federal de São João Del-Rei/UFSJ - Campus de Sete Lagoas - Rodovia MG 424 - Km 65 - $35701-970$ - Sete Lagoas, MG christiano@ufsj.edu.br
} 
Digestibility is the percentage of proteins hydrolyzed by digestive enzymes and absorbed by the organism in the form of amino acids or any other nitrogen compound (MONTEIRO et al., 2004). Protein digestibility is a nutritional parameter that evaluates the use of a protein source. It can be influenced by several factors, such as phenolic compounds, protein inhibitors and thermal treatment (MESQUITA et al., 2007). Therefore, protein digestibility becomes a condition of protein quality, since a certain amino acid may be present in a protein, but not necessarily available for the organism. Thus, proteins cannot be used by the organism without being digested (PIRES et al., 2006).

The in vitro protein digestibility techniques are based on the digestion of the samples with proteolytic enzymes under standardized conditions. The differences between them were the number and nature of the enzymes to be used and the final measurements to be carried out. Two of these techniques, the $\mathrm{pH}$ drop and $\mathrm{pH}$-static techniques, are used because they are cheaper methods and require less time, labor force and physical space (PIRES et al., 2006).

The present work aimed at determining protein in vitro digestibility in whole and defatted animal and vegetable sources, thus assessing whether lipids affect in vitro digestibility and, consequently, the mathematical adjustment that correlates the in vivo digestibility with the in vitro digestibility.

\section{MATERIAL AND METHODS}

The present work was carried out at the Laboratory of de Enzymology, Biochemistry of Proteins and Peptides of the Instituto de Biotecnologia Aplicada à Agropecuária (BIOAGRO) of the Universidade Federal de Viçosa (UFV), in Viçosa, MG.

The following protein sources were used: oats, beef meat, chicken meat, fish meat, pork meat, red beans, milk powder, textured soy protein (TSP), quinoa (a glutenfree cereal which is a high quality protein alternative), soybean IAC 17 (resistant to the attack of the insect Anticarsia gemmatalis Hübner, 1818), soybean IAC 24 (resistant to the attack of the insect Anticarsia gemmatalis), soybean IAC PL-1 (conventional), soybean UFV TN 105 (free from lipoxygenase) and soybean UFV TN $105 \mathrm{KL}$ (free from the Kunitz trypsin and lipoxygenase inhibitor).

The soybeans IAC 17, IAC 24 and IAC PL1 were provided by Dr. André Luiz Lourenção from the Instituto Agronômico de Campinas.

\section{Preparation of the samples}

Oat and commercial milk powder were used. The beef (minced chuck), chicken (chicken chest without skin), fish (hake fillet) and pork (ham without apparent fat) meats were cooked with water in domestic pans, using a proportion of 1:1 (p/v), until the water dried. After cooked, the meats were frozen at $-80^{\circ} \mathrm{C}$, dehydrated by lyophilization (Edwards lyophilizer- super Modulyo) at pressure of $10^{-1} \mathrm{mbar}$ and the condenser temperature $-40^{\circ} \mathrm{C}$ for 24 hours and minced in an Arno domestic multiprocessor.

For the achievement of the cooked bean flour, a manual selection of the grains was initially carried out for the elimination of impurities and dirt. Later, the grains were cleaned and cooked in water, at the proportion of 1:1,5 $(\mathrm{p} / \mathrm{v})$, in a domestic pressure pan, during 40 minutes. After cooked, they were dried in a greenhouse with air circulation $\left(6 \mathrm{~h} / 105^{\circ} \mathrm{C}\right)$. Next, they were minced in a domestic multiprocessor, using 20-mesh sieves.

The TSP and quinoa, acquired from a shop in Viçosa, MG, were minced in an Arno domestic multiprocessor for flour preparation. The soybeans IAC 17, IAC 24, IAC PL-1, UFV TN 105, UFV TN $105 \mathrm{KL}$ and hulled soybean were submitted to thermal treatment in a greenhouse with air circulation, with dry heat of $105^{\circ} \mathrm{C}$ for 6 hours. Next, the grains were ground and the soybean flour was obtained.

\section{Determination of the protein content}

The nitrogen content was determined by the semimicro-Kjeldhal method ( 984.13 method), according to Association of Official Analytical Chemists - AOAC (1995). The factor 6.25 was used for the calculation of the conversion of nitrogen into proteins.

\section{Extraction of fat from the samples}

The samples were defatted by the intermittent Soxhlet method, AOAC Official Method 920.85 (AOAC, 1984). The method is based on the extraction of the lipid fraction with petroleum ether. After the extraction and removal of the solvent, the quantity of lipids present was gravimetrically determined, and the defatted sample was stored.

For the milk powder, it is not possible to achieve defatted samples by the intermittent Soxhlet method, since the binding between proteins and lipids, forming micelles during the processing, hinders the removal of all the lipid content. For this reason, samples of whole and skimmed milk were purchased in the market. The lipid content in the 
whole milk powder was determined with the use of Teichert butyrometer, as described by Silva et al. (1997). The method is based on the separation and quantification of fat by means of the treatment of $2.5 \mathrm{~g}$ of sample, after complete dissolution in $10 \mathrm{~mL}$ of water, with $10 \mathrm{~mL}$ of sulfuric acid and $1 \mathrm{~mL}$ of isoamilic alcohol. The acid dissolves the proteins that involve the globules of fat, releasing it. The heat liberation melts fat, favoring its separation by the extractor (isoamilic alcohol). The reading is performed directly in the butyrometer graded scale after centrifugation and immersion in water bath.

\section{In vitro digestibility}

To determine the in vitro digestibility, two methods were analyzed per essay, using an enzymatic system containing the enzymes trypsin and pancreatin.

The enzyme solution containing $2.5 \mathrm{mg}$ of trypsin and $1.6 \mathrm{mg}$ of pancreatin (a mixture of the enzymes amylase, trypsin, lipase, ribonuclease and other proteases) per $\mathrm{mL}$ of the solution was prepared before each series of tests and maintained in ice bath. This solution was used for both methods.

The equations achieved by Pires et al. (2006) were used for the evaluation of the in vitro digestibility. They were differentiated for animal and vegetable sources or for the association of both.

\section{pH drop Method}

The $\mathrm{pH}$ of $50 \mathrm{~mL}$ of the protein suspension in distilled water (containing $6.25 \mathrm{mg}$ of protein $/ \mathrm{mL}$ ) was adjusted for $\mathrm{pH} 8$, under agitation, in water bath at $37^{\circ} \mathrm{C}$. Five milliliters of the enzyme solution were added to the protein suspension maintained in water bath at $37^{\circ} \mathrm{C}$. The $\mathrm{pH}$ drop was determined after the addition of the enzyme solution during 10 minutes, described by Hsu et al. (1977), with modifications made by Pires et al. (2006).

The equation described by Pires et al. (2006) was used to verify the effect of lipids on the $\mathrm{pH}$ drop method, for both animal and vegetable proteins, except for casein.

$\% \mathrm{D}=-230.65 \mathrm{pH}^{2}+3270.9 \mathrm{pH}-11505\left(\mathrm{r}^{2}=0.7904\right)$

\section{pH-static Method}

The $\mathrm{pH}$ of $50 \mathrm{~mL}$ of the protein suspension in distilled water (containing $6.25 \mathrm{mg}$ of protein $/ \mathrm{mL}$ ) was adjusted for $\mathrm{pH} 8$, under agitation, in water bath at $37^{\circ} \mathrm{C}$. Five milliliters of the enzyme solution were added to the protein suspension maintained in water bath at $37^{\circ} \mathrm{C}$. Next, $\mathrm{NaOH} 0.1 \mathrm{~N}$ was added, at an amount sufficient to maintain the $\mathrm{pH}$ at 8.0, regardless of the time of 10 minutes, provided that the $\mathrm{pH}$ drop did not vary more than 0.03 units in $1 \mathrm{~min}$. The factor 0.03 was achieved by the casein hydrolysis, during the $\mathrm{pH}$ drop, between 9 and 10 minutes, because, from that point on, the difference in the $\mathrm{pH}$ is very low and, therefore, nonsignificant (CRUZ et al., 2003). Later, the volume of $\mathrm{NaOH}$ spent during the test was determined, described by Cruz et al. (2003), with modifications made by Pires et al. (2006).

To verify the lipid influence on the $\mathrm{pH}$-static method, the equation described by Pires et al. (2006) was used, for animal and vegetable proteins.

$\% D=1.4048 x^{2}+11.573 x+68.524\left(r^{2}=0.8378\right)$

where, $x=m L$ of $\mathrm{NaOH}(0.1 \mathrm{~N})$ added

Although equations 1 and 2 show $\mathrm{r}^{2}$ less than 0.9 them were accepted due to the fact that the methods are easy and inexpensive, with a remarkably high correlation.

\section{Statistical Design}

The results were submitted to the analysis of variance (ANOVA) with $1 \%$ of significance for the determination of the $\mathrm{F}$ value. For the significant values, it was used the Tukey test at $1 \%$ of probability, for average comparison of samples with each other and compare the means of whole and defatted samples. The statistical analyses were processed with the use of the Saeg 9.1 software system (EUCLYDES, 1983).

\section{RESULTS AND DISCUSSION}

The Table 1 presents the content of proteins in the samples studied, calculated based on wet basis. Beef, chicken and pork meats presented the highest protein content, without difference among them $(\mathrm{p}>0.01)$, followed by fish meat $(70.78 \%)$ and TSP $(52.12 \%)$, which presented difference $(\mathrm{p}<0.01)$.

The soybeans IAC PL-1 (45.21\%), IAC 17 (44.40\%), IAC $24(44.06 \%)$ and UFV TN 105 KL (41.84\%) presented the same protein values at the level of $1 \%$ of probability, while there was difference $(\mathrm{p}<0.01)$ for the soybean UFV TN 105 (36.12\%). Whole milk powder $(24.77 \%)$ and red beans $(23.40 \%)$ did not present difference between them, either $(\mathrm{p}>0.01)$.

For Neves et al. (2006), the seeds of legumes used for food contain about $20 \%-30 \%$ of protein, except for the soybean and lupine (Lupinus - one of the richest sources of proteins among the seeds of legumes), which present higher contents. Such observations are corroborated by the results of this work, in which the average content of proteins in beans was $24.42 \%$ and in soybean, $42.17 \%$. 
Table 1 - Content of proteins in the dry basis samples analyzed.

\begin{tabular}{cc}
\hline Samples & Proteins $(\mathrm{g} / 100 \mathrm{~g})$ \\
\hline Oat & $18.13 \pm 0.41^{\mathrm{h}}$ \\
Quinoa & $12.93 \pm 0.18^{\mathrm{i}}$ \\
Beef Meat & $75.20 \pm 0.82^{\mathrm{a}}$ \\
Chicken Meat & $75.04 \pm 0.54^{\mathrm{a}}$ \\
Fish Meat & $70.78 \pm 0.62^{\mathrm{b}}$ \\
Pork Meat & $72.27 \pm 1.06^{\mathrm{a}, \mathrm{b}}$ \\
Skimmed Milk Powder & $32.94 \pm 2.09^{\mathrm{f}}$ \\
Whole Milk Powder & $24.77 \pm 1.80^{\mathrm{g}}$ \\
Red Beans & $23.40 \pm 0.05^{\mathrm{g}}$ \\
Textured Soybean Protein (TSP) & $52.12 \pm 0.27^{\mathrm{c}}$ \\
Soybean IAC 17 & $44.40 \pm 0.36^{\mathrm{d}, \mathrm{e}}$ \\
Soybean IAC 24 & $44.06 \pm 1.59^{\mathrm{d}, \mathrm{e}}$ \\
Soybean IAC PL-1 & $45.21 \pm 1.34^{\mathrm{d}}$ \\
Soybean UFV TN 105 & $36.12 \pm 0.35^{\mathrm{f}}$ \\
Soybean UFV TN 105 KL & $41.84 \pm 1.00^{\mathrm{d}, \mathrm{e}}$ \\
\hline
\end{tabular}

The results are triplicate averages.

Averages $( \pm \mathrm{SD})$ followed by the same letter do not differ by the Tukey test at $1 \%$ of probability.

Among all the samples studied, oat (18.13\%) and quinoa $(12.93 \%)$ presented the lowest protein content, differing from each other and from the others $(\mathrm{p}<0.01)$. These contents, however, are higher than those usually found for other cereals, such as maize, rice and wheat.

\section{Lipid Content}

The Table 2 presents the lipid content of the samples analyzed. The whole milk powder is the source with the highest lipid content $(26.72 \%)$. It differs from the others $(\mathrm{p}<0.01)$, and is followed by pork meat $(22.73 \%)$. Textured soybean protein was the sample with the lowest lipid content, only $0.58 \%$.

Moraes et al. (2006) achieved the average of $20.60 \%$ for the lipid content of soybean, which varied from $24.03 \%$ to $18.56 \%$. Vieira et al. (1999) found oil percentages varying from $22.24 \%$ to $23.80 \%$, observing that the oil content decreases with the increase of the protein content.

In the present work, among the soybean samples, the soybean without lipoxygenase (UFV TN 105) presented the highest lipid content $(20.27 \%)$, differing from the other varieties: IAC 17 (17.78\%), UFV TN 105 KL (16.17\%), IAC PL-1 (15.95\%), IAC 24 (11.84\%), with $\mathrm{p}<0.01$. This high lipid percentage in the soybean UFV TN 105 may explain its low protein content.

Table 2 - Lipid contents of the samples analyzed.

\begin{tabular}{cc}
\hline Samples & Lipid $(\mathrm{g} / 100 \mathrm{~g})$ \\
\hline Oat & $7.98 \pm 0.05^{\mathbf{f}}$ \\
Quinoa & $5.62 \pm 0.01^{\mathbf{f}, \mathbf{g}}$ \\
Beef Meat & $19.30 \pm 0.08^{\mathbf{c}}$ \\
Chicken Meat & $4.91 \pm 0.25^{\mathbf{g}}$ \\
Fish Meat & $1.35 \pm 0.16^{\mathbf{h}}$ \\
Pork Meat & $22.73 \pm 1.48^{\mathbf{b}}$ \\
Whole Milk Powder & $26.72 \pm 0.02^{\mathbf{a}}$ \\
Red Beans & $1.35 \pm 0.03^{\mathbf{h}}$ \\
Textured Soybean Protein (TSP) & $0.58 \pm 0.01^{\mathbf{i}}$ \\
Soybean IAC 17 & $17.78 \pm 0.52^{\mathbf{c , d}}$ \\
Soybean IAC 24 & $11.84 \pm 0.91^{\mathbf{e}}$ \\
Soybean IAC PL-1 & $15.95 \pm 0.73^{\mathbf{d}}$ \\
Soybean UFV TN 105 & $20.27 \pm 0.05^{\mathbf{b}, \mathbf{c}}$ \\
Soybean UFV TN 105 K L & $16.17 \pm 0.08^{\mathbf{d}}$ \\
\hline
\end{tabular}

The results are averages in duplicates.

Averages $( \pm \mathrm{SD})$ followed by the same letter do not differ by the Tukey test at $1 \%$ of probability.

\section{In vitro Digestibility}

The values achieved for the in vitro digestibility of the whole samples studied varied from $32.13 \%$ (UFV TN 105 - soybean free from lipoxygenase) to $90.76 \%$ (TSP) (Table 3). This great variety was expected, since the foods analyzed were from vegetable origin, which presents lower protein digestibility because of the antinutritional factors, and animal origin, with higher digestibility.

In a study carried out by Pires et al. (2006), animal proteins presented higher values of true digestibility (achieved by in vivo essay with animals) than vegetable proteins, possibly due to the absence of antinutritional factors, which clearly contribute to diminish digestibility in vegetable foods. According to Bressani (1989), most animal proteins present good digestibility, implying in efficient amino acid absorption. In the present study, the highest digestibility was presented by textured soybean protein (vegetable source), $90.76 \%$, followed by meats (animal source), without difference among them (Table 3). The higher digestibility presented by TSP can be explained by the processing to which the soybean bran is submitted, in which the antinutritional factors are removed, resulting in an improvement in protein digestibility. 
Table 3 - Values of in vitro digestibility of the whole and defatted protein samples, calculated by the equation of the PH drop and pH-static methods.

\begin{tabular}{ccccc}
\hline \multirow{2}{*}{ Samples } & \multicolumn{2}{c}{ \% Digestibility } & \multicolumn{2}{c}{ pH-static $^{* * *}$} \\
& Whole & PH drop* & Whole & Defatted \\
\hline Quinoa & $72.61^{\mathbf{b}}$ & 68.35 & $75.59^{\mathbf{b}, \mathbf{c}}$ & 74.54 \\
Beef meat & $83.89^{\mathbf{a}, \mathbf{b}}$ & 83.67 & $75.77^{\mathbf{b , c}}$ & 76.60 \\
Chicken Meat & $78.39^{\mathbf{a}, \mathbf{b}}$ & 55.89 & $76.41^{\mathbf{b , c}}$ & 72.17 \\
Fish meat & $90.14^{\mathbf{a}}$ & 88.04 & $79.27^{\mathbf{a}, \mathbf{b}}$ & 80.64 \\
Pork meat & $71.67^{\mathbf{b}}$ & 66.21 & $74.29^{\mathbf{b}, \mathbf{c}}$ & 71.18 \\
Milk Powder & $85.62^{\mathbf{a}, \mathbf{b}}$ & 86.87 & $84.53^{\mathbf{a}}$ & 82.40 \\
Red beans & $46.00^{\mathbf{c}}$ & 43.82 & $73.33^{\mathbf{b}, \mathbf{c}}$ & 73.68 \\
TSP & $90.76^{\mathbf{a}}$ & 91.17 & - & - \\
Soybean IAC 17 & $52.91^{\mathbf{c}}$ & 62.36 & $71.90^{\mathbf{c}}$ & 71.63 \\
Soybean IAC 24 & $46.16^{\mathbf{c}}$ & 35.85 & $71.86^{\mathbf{c}}$ & 71.01 \\
Soybean IAC PL-1 & $52.21^{\mathbf{c}}$ & 51.97 & $72.03^{\mathbf{c}}$ & 70.86 \\
Soybean UFV TN 105 & $32.13^{\mathbf{d}}$ & 42.55 & $71.69^{\mathbf{c}}$ & 72.13 \\
Soybean UFV TN 105 KL & $57.11^{\mathbf{c}}$ & 55.00 & $71.78^{\mathbf{c}}$ & 71.70 \\
\hline
\end{tabular}

Averages followed by the same letter do not differ by the Tukey test at $1 \%$ of probability.

*Equation 1:\% $=-230.65 \mathrm{pH}^{2}+3270.9 \mathrm{pH}-11505\left(\mathrm{R}^{2}=0.7904\right)$.

**Equation $2: \% \mathrm{D}=-1.4048 \mathrm{x}^{2}+11.573 \mathrm{x}+68.524\left(\mathrm{R}^{2}=0.8378\right)$; in which: $\mathrm{x}=\mathrm{mL}$ of $\mathrm{NaOH}(0.1 \mathrm{~N})$ added.

***The statistical difference between whole and defatted samples is not presented as there was no difference following the Tukey test.

By the $\mathrm{pH}$ drop in vitro digestibility method, the soybeans UFV TN $105 \mathrm{~K} \mathrm{~L}$ (57.11\%), IAC 17 (52.91\%), IAC PL-1 $(52.21 \%)$ and IAC $24(46.16 \%)$ did not differ significantly from one another at $1 \%$, in opposition to the soybean UFV TN 105 (32.13\%), which obtained the lowest digestibility of all the samples, with statistical difference $(p<0.01)$. Red beans presented $46 \%$ of digestibility, without difference from the soybean digestibility (Table 3 ).

In spite of the high protein content, the nutritional quality of vegetable reserve proteins is low, in comparison to animal proteins. Among other things, it is due to structural characteristics, digestibility and deficiency in sulfur amino acids in proteins, as well as the presence of antinutritional factors, mainly trypsin and lectin inhibitors (NEVES et al., 2006).

In the work carried out by Pires et al. (2006), among all the proteins analyzed, the conventional soybean presented the lowest true digestibility $(71.76 \%)$, without differing statistically from the soybean free from the Kunitz trypsin and lipoxygenase inhibitor, which presented $74.26 \%$ of digestibility. These data corroborate the results of the present work, in which the conventional soybean (Soybean
IAC PL-1) presented $52.21 \%$ and the soybean free from the Kunitz trypsin and lipoxygenase inhibitor (UFV TN $105 \mathrm{KL}$ ) presented $57.11 \%$ of protein digestibility, without differing from each other ( $p>0.01)$. It demonstrates that the genetic elimination of this inhibitor did not lead to a significant increase in protein digestibility. Monteiro et al. (2004) found a true digestibility of $36 \%$ for the conventional soybean variety and $90.59 \%$ for the soybean free from KTI-LOX-.

A possible explanation for the differences among the values found in Monteiro et al. (2004) e Pires et al. (2006) and the present work may be the method used for sample preparation, such as the binomial time/temperature used in the thermal treatment of soybean. Herkelman et al. (1992), studying the effect of the cultivars (with regular content $x$ low content of KTI) and thermal treatment on the apparent digestibility of the protein of the soybean administered to swine, observed that the animals exposed to diets with conventional soybean presented lower performance, in comparison to the animals that received diets with soybean with low content of KTI. However, an adequate thermal treatment is required to improve the nutritional value of both types of soybean. 
The present work found, for red beans, a protein digestibility of $46.00 \%$ for the $\mathrm{pH}$ drop method (Equation 1) and $73.33 \%$ for the $\mathrm{pH}$-static method (Equation 2). By comparing the results of the in vitro digestibility to those found in literature, whose percentages varied from 48.80 to $73.00 \%$ (EGG-MENDONÇA et al., 2003; RIOS et al., 2003), it is observed that the results of this work meet the expectations. But it must be pointed out that the value of the in vitro digestibility by the $\mathrm{pH}$-static method is closer to the in vivo digestibility, as observed by Cruz et al. (2003) (88.61\% of true digestibility for red beans) and Pires et al. (2006) (78.70\% of true digestibility for the beans Pérola).

\section{Lipid influence on the in vitro digestibility method}

The Table 3 presents the digestibility values of the whole and defatted samples analyzed by the $\mathrm{pH}$ drop and $\mathrm{pH}$-static methods, respectively. The analyses of variance demonstrated that there is no statistical difference $(p>0.01)$ between the in vitro digestibility of the whole and defatted samples, by the $\mathrm{pH}$ drop and $\mathrm{pH}$-static methods. Thus, it can be said that lipids do not affect the determination of protein digestibility, when these methods of in vitro protein digestibility are used.

By comparing the in vitro protein digestibility found in this work to the in vivo digestibility found by Pires et al. (2006), it is possible to affirm that the best equation to evaluate vegetable protein sources is that of the $\mathrm{pH}$-static method, since the in vivo values were $74.26 \%$ for the soybean free from the lipoxygenase and trypsin inhibitor and $71.76 \%$ for the conventional soybean. Beans achieved a digestibility of $78.70 \%$. These values are closer to those found in the $\mathrm{pH}$-static method, in which the soybean digestibility varied from 71.78 to $72.03 \%$ and beans digestibility was $73.33 \%$.

For the animal protein sources, the in vitro $\mathrm{PH}$ drop method presented the closest values to the in vivo method, with meats presenting a digestibility of $91.13-93.37 \%$, while the present work found $71.67-90.14 \%$.

\section{CONCLUSIONS}

Animal proteins presented higher values of in vitro digestibility, compared to vegetable proteins, except for the textured soybean protein, which presented higher digestibility due to the processing it underwent. Among the meats, fish meat was the protein with the highest digestibility, but it did not differ from the other samples of meat, indicating that protein sources from meats presented the same digestibility.
The textured soybean protein presented a higher protein digestibility value, compared to the conventional soybean (IAC PL 1) and the soybean free from the Kunitz trypsin and lipoxygenase inhibitor (UFV TN $105 \mathrm{KL}$ ), demonstrating the improvement in the digestibility of proteins derived from soybean-based products submitted to thermal processing.

In the present work, it was also verified that the lipid content presented no effect on protein digestibility, which indicates that the lipid from the samples did not affect the $\mathrm{pH}$ drop and $\mathrm{pH}$-static in vitro digestibility methods. Therefore, suggest samples do not need to be defatted before the analysis of the in vitro digestibility, using an enzymatic system containing the enzymes trypsin and pancreatin, which facilitates even more the use of these methods for foods with high lipid levels in food industries.

\section{ACKNOWLEDGEMENTS}

The authors thank FAPEMIG and CNPq for the financial support.

\section{REFERENCES}

ASSOCIATION OF OFFICIAL ANALYTICAL CHEMISTS. Official methods of analysis. 16.ed. Washington, 1995.

Official methods of analysis of the Association of Official Analytical Chemists. 14.ed. Arlington, 1984. 1141p.

BRESSANI, R. Revisión sobre la calidad del grano de frijol. Archives Latinoamericanos Nutricion, Caracas, v.39, n.3, p.419-442, 1989.

CRUZ, G.A.D.R. et al. Protein quality and in vivo digestibility of different varieties of bean (Phaseolus vulgaris L.). Brazilian Journal of Food Technology, Campinas, v.6, n.2, p.157-162, 2003.

Evaluation of the protein digestibility, protease inhibitor and dietary fibers of different bean varieties (Phaseolus vulgaris L.). Brazilian Journal of Food Technology, Campinas, v.7, n.2, p.103-109, 2004.

EGG-MENDONÇA, C.V. do C. et al. Quantificação de polifenóis e digestibilidade protéica de famílias de feijoeiro comum. Ciência e Agrotecnologia, Lavras, v.27, n.4, p.858-864, jul./ago. 2003. 
ESTEVES, A.N. et al. Comparação química e enzimática de seis linhagens de feijão (Phaseolus vulgaris L.). Ciência e Agrotecnologia, Lavras, v.26, n.5, p.999-1005, set./out. 2002.

\section{EUCLYDES, R.F. Sistema de análises estatísticas e genéticas - SAEG. Viçosa, MG: UFV, 1983. 68p.}

HERKELMAN, K.L. et al. Apparent digestibility of amino acids in raw and heated conventional and low trypsin inhibitor soybeans for pigs. Journal of Animal Science, Champaign, v.70, p.818-826, 1992.

HSU, H.W. et al. Multienzyme technique for estimating protein digestibility. Journal of Food Science, Chicago, v.42, n.5, p.1269-1273, 1977.

\section{MESQUITA, F.R.; CORREA, A.D.; ABREU, C.M.P.}

Linhagens de feijão (Phaseolus vulgaris L.): composição química e digestibilidade protéica. Ciência e

Agrotecnologia, Lavras, v.31, n.4, p.812-816, jul./ago. 2007.

MILLWARD, D.J. et al. Protein quality assessment: impact of expanding understanding of protein and amino acid needs for optimal health. American Journal of Clinical Nutrition, New York, v.87, n.5, p.1576S-1581S, May 2008.

MONTEIRO, J.B.R. et al. Avaliação da qualidade protéica de dois formulados em pó, à base de soja enriquecidos com zinco, selênio e magnésio para utilização em nutrição enteral. Ciência e Tecnologia de Alimentos, Campinas, v.24, n.1, p.6-10, 2004.

MORAES, R.M.A. et al. Caracterização bioquímica de linhagens de soja com alto teor de proteína. Revista de Pesquisa Agropecuária Brasileira, Brasília, v.41, n.5, p.715-729, maio 2006
NEVES, V.A.; SILVA, S.I.; SILVA, M.A. Isolamento da globulina majoritária, digestibilidade in vivo e in vitro das proteínas do tremoço-doce (Lupinus albus L.), var. multolupa. Ciência e Tecnologia de Alimentos, Campinas, v.26, n.4, p.832-840, out./dez. 2006.

PIRES, C.V. et al. Digestibilidade in vitro e in vivo de proteínas de alimentos: estudo comparativo.

Alimentos e Nutrição, Araraquara, v.17, n.1, p.13-23, jan./mar. 2006.

RIOS, A. de O.; ABREU, C.M.P.; CORRÊA, A.D. Efeito da estocagem e das condições de colheita sobre algumas propriedades físicas, químicas e nutricionais de três cultivares de feijão (Phaseolus vulgaris L.). Ciência e Tecnologia dos Alimentos, Campinas, v.23, p.39-45, dez. 2003. Suplemento.

SILVA, P.H.F. et al. Físico-química do leite e derivados: métodos analíticos. Juiz de Fora: UFJF, 1997. 190p.

VIEIRA, C.R.; CABRAL, L.C.; OLIVEIRA, A.C.P. Composição centesimal e conteúdo de aminoácidos, ácidos graxos e minerais de seis cultivares de soja destinadas à alimentação humana. Pesquisa Agropecuária Brasileira, Brasília, v.34, n.7, p.1277-1283, jul. 1999.

WONG, K.H.; CHEUNG, P.C.K. Nutritional evaluation of some subtropical red and green seaweeds part II: in vitro protein digestibility and amino acid profiles of protein concentrates. Food Chemistry, London, v.72, p.11-17, 2001.

WORLD HEALTH ORGANIZATION. Diet, nutrition and the prevention of chronic diseases: report of a joint WHO/FAO expert consultation. Geneva, 2003. 